\title{
Quality surveillance of surface water catchments in selected Obokun rural communities, in South-Western Nigeria
}

\author{
OLAITAN Janet Olubukola, AKINDE Sunday Babatunde*, SALAMI Adejoke Omosile and \\ AKINYODE Oluwafemi Ayobami
}

Department of Biological Sciences, College of Science, Engineering and Technology, Osun State University, P.M.B. 4494, Osogbo, Nigeria.

Accepted 20 August, 2013

\begin{abstract}
In most rural communities in Nigeria, access to potable water is still a challenge. Water quality monitoring was conducted on six (6) surface water catchments in Obokun rural communities in SouthWestern Nigeria. Parameters were determined using internationally accepted procedures. Among the examined water chemical parameters, only $\mathrm{NO}_{3}(50.0-154 \mathrm{mg} / \mathrm{l})$ and $\mathrm{Mg}(20.0-110 \mathrm{mg} / \mathrm{l})$ exceeded the WHO and the Nigerian Standard for Drinking Water Quality (NSDWQ) recommended thresholds for potable water. All the surface water samples contained total heterotrophic bacteria (THB) (1100 - 5900 $\mathrm{cfu} / \mathrm{ml})$ and total coliform $(9.00-78.0 \mathrm{cfu} / 100 \mathrm{ml})$ above tolerant level. Total heterotrophic fungi (THF) were found in $1.00-7.00 \mathrm{cfu} / \mathrm{ml}$ density range. All the samples $(100 \%)$ contained thermotolerant coliform (4.0 - $11.0 \mathrm{cfu} / 100 \mathrm{~m} \mathrm{I})$, Escherichia coli $(4.00-7.00 \mathrm{cfu} / 100 \mathrm{ml})$, faecal streptococci $(1.00-5.00$ $\mathrm{cfu} / \mathrm{ml})$ and Salmonella $(1.00-8.00 \mathrm{cfu} / 100 \mathrm{ml})$ while $67 \%$ contained Shigella $(1.00-6.00 \mathrm{cfu} / 100 \mathrm{ml})$. Presence of pathogenic microorganisms in water samples is indicative of faecal contamination. Multidrug resistance of Pseudomonas aeruginosa, Salmonella typhi, Shigella flexneri, E. coli and Corynebacterium ulcerans showed that these organisms could pose a serious health threat to the users of the water from these rivers. The qualities of surface water samples used for this study were therefore not suitable for human consumption without adequate treatment. However, most rural community people still rely on surface water for drinking and other domestic use. Identification of cost-effective local water treatment techniques and implementation of WHO Water Safety Plan (WSP) will improve water quality and minimize risks to human health.
\end{abstract}

Key words: surface water, rural water, quality surveillance, microorganisms, antibiotic sensitivity.

\section{INTRODUCTION}

Lack of pipe-borne water and inadequate potable water interventions in the rural areas of South-Western Nigeria are directly responsible for continued dependence of the people on raw surface waters within their vicinity for drinking and other domestic uses.
Though the hydrosphere is estimated to contain about 1.36 billion $\mathrm{Km}^{3}$, only about $0.65 \%$ of the water, existing as freshwater in rivers, streams, springs and aquifers, is available for human use; the remaining $99.35 \%$ is locked up in seas and oceans (Wicander and Monroe, 2005). 
However, geological constraints limit accessibility of many human communities to water that is adequate in terms of quantity, quality and sustainability while the situation is further aggravated by human anthropogenic activities.

Potable water, also referred to as drinking water in reference to its intended use, is defined as water which is fit for consumption by humans and other animals (Tchobanoglous et al., 2003). Although some local government authorities in Osun State, South-Western Nigeria made attempt to provide hand-pump wells and boreholes in most rural communities, these water interventions are, however, not adequate, not properly cited and not maintained regularly. Therefore, the usual source of drinking water still remains natural streams, rivers and ponds which are mostly untreated and associated with various health risks (Agbaire and Obi, 2009).

It is estimated that in the world, over 3 million people mostly from rural populace die annually from water-borne diseases (WHO, 1997a). Water-borne diseases are among the most recent re-emerging infectious diseases throughout the world. The most well known water-borne diseases such as cholera, dysentery and typhoid are the leading cause of morbidity and mortality (WHO, 1997a). For example, cases of cholera outbreak were in the news between August and September, 2011 in Osun State. This incident however made the news because of the reported fatalities in the affected rural communities within the relatively short period. Lots of other water-borne sicknesses occur on daily basis in Nigeria especially among rural people and city slum dwellers due to non-availability of quality water and unhygienic attitude of the people.

A multitude of human activities is usually connected with severe impacts on the environment (Decker et al., 2002). Poor sanitation and wastewater disposal are also directly responsible for poor water quality especially in the rural areas. In most rural communities, open defecation close to natural water catchments is a common practice. These together with lack of adequate health infrastructure constitute risks to human health.

Up till now, provision of a sustainable and safe drinking water alternative in the rural communities is a great challenge for the developing countries like Nigeria and larger percentage of people will continue to depend on poor traditional sources that often provide unsafe domestic water. Consistent water quality monitoring of natural water catchments in large number of rural communities is therefore paramount and will serve as a proactive step towards identification of health related risks associated with polluted natural water catchments in the area.

Water quality characteristics of various water catchments in Nigeria have been documented (Chima and Okpe, 2008; Fadare and Olawuni, 2008; Oluyemi et al., 2010; Akinde et al., 2011; Chinedu et al., 2011). Most of the authors focused more on available water catchments within the major cities in Nigeria. Their assessment of water quality also concentrated more on physicochemical characterization while little information exists concerning the microbiological status of the studied water sources.

The present work therefore seeks to assess the physico-chemical and microbiological characteristics of selected surface waters that serve as major drinking water sources in rural communities in South-Western Nigeria. The data for six (6) surface water catchments in selected rural communities in Obokun Local Government Area of Osun State, South-Western Nigeria is hereby presented and discussed.

\section{MATERIALS AND METHODS}

\section{Study area}

Water quality surveillance was conducted on surface water bodies in six (6) rural communities within Obokun which serves as the study area. Obokun is one of the local government areas in Osun State covering an area of $157 \mathrm{~km}^{2}$ in South-Western Nigeria with an average population of 116,850 at the 2006 census (Figure 1). The primary occupations of the people are farming and rearing of animals which engage members of households across gender and age divides. Absence of basic infrastructural facilities including good road network reduces commercial activities in the study communities and results in low income level.

Scattered around the study communities are various failed water supply donor projects. This is a direct consequence of poor technological choice, improper installation, sub-standard construction and lack of routine maintenance. This accounts for people's continuous dependence on the raw surface water within their vicinity for drinking and other domestic use. The local names of the surface water bodies used in this study and the geographic coordinates of the points where they are usually accessed by the people are presented in Table 1.

\section{Sample collection}

Water samples were taken from locations that are representative of the water source and the points at which the community people fetch the water (WHO, 1997b). Samples were obtained at minimum of three (3) different points and mixed together in sterile container to form composite samples for physico-chemical characterization. Parameters such as $\mathrm{pH}$, temperature, conductivity and turbidity as well as the organoleptic properties were determined in situ immediately after sample collection.

Sub-samples for physico-chemical analysis were transferred into $2 \mathrm{~L}$ plastic containers in triplicates. Samples for microbiological analysis were aseptically obtained directly at six (6) different points using $1 \mathrm{~L}$ sterile plastic containers.

All samples were immediately placed in a lightproof insulated box containing ice and transported to the laboratory. Samples were stored in the refrigerator at $4 \pm 2{ }^{\circ} \mathrm{C}$ prior to analysis. Analyses of all samples were performed within $24 \mathrm{~h}$ as stipulated by WHO (1997b).

\section{Laboratory analysis of water samples}

Physical characteristics were measured in accordance with APHA 2510B, APHA 4500- $\mathrm{H}^{+} \mathrm{B}$ and ASTM D 4972 (APHA, 1998; ASTM, 1999). The $\mathrm{pH}$, temperature, conductivity and dissolved oxygen (DO) of the water samples were determined electrometrically using 340i WTW multimeter. Prior to use, the equipment was calibrated appropriately according to manufacturer's instructions. Turbidity was also measured in situ using T930712 turbidity meter. The odour and the colour of the water samples were determined by physical observation (Ajayi and Adejumo, 2011).

Nitrite and nitrate were determined colorimetrically by UV4-100 


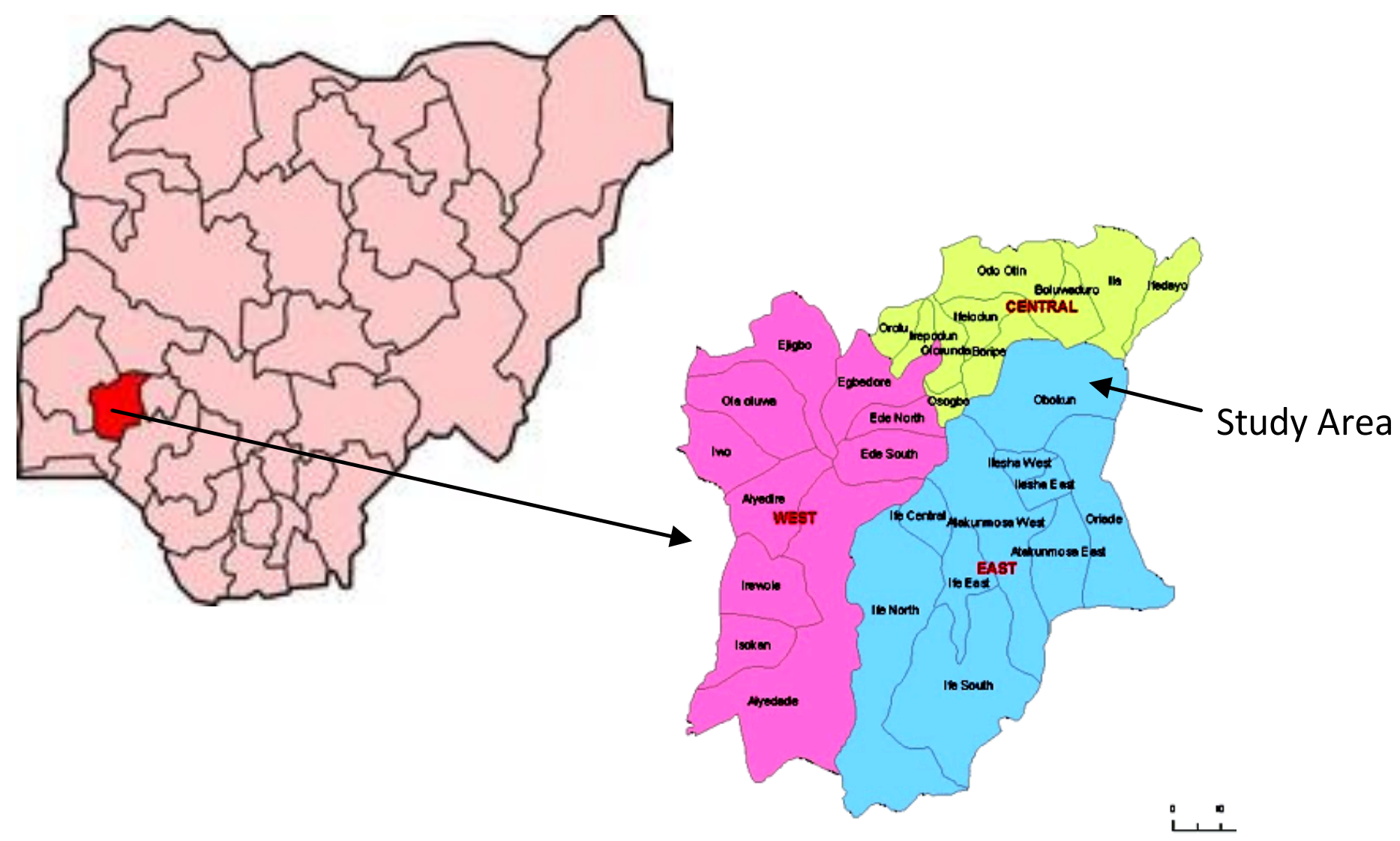

Figure 1. Map of the Study Site (NICOCUSA, 2013).

Table 1. Geographic coordinates of the surface water bodies at the access points in the study area.

\begin{tabular}{lllrr}
\hline \multirow{2}{*}{ Name of Surface Water Body } & \multirow{2}{*}{ Location } & \multirow{2}{*}{ Type of Water Source } & \multicolumn{2}{c}{ Coordinate at the Access Point } \\
\cline { 4 - 5 } & & & Northing & Easting \\
\hline Lagodo 1 & Ago Eesa & Stream & $07.80200^{\circ}$ & $004.66922^{\circ}$ \\
Lagodo 2 & Ago Eesa & Stream & $07.80143^{\circ}$ & $004.66855^{\circ}$ \\
Odo Opo & Ibala & Stream & $07.70856^{\circ}$ & $004.73523^{\circ}$ \\
Odo Gani & Oja Tuntun & Wetland & $07.80132^{\circ}$ & $004.66807^{\circ}$ \\
Odo Araba & Ibisomi 1 & Pond & $07.74490^{\circ}$ & $004.69235^{\circ}$ \\
Odo Elere & Ibisomi 2 & Wetland & $07.74470^{\circ}$ & $00.469224^{\circ}$ \\
\hline
\end{tabular}

Unicam UV/VIS spectrophotometer in accordance with EPA 352.1 and APHA $4500-\mathrm{NO}_{3}{ }^{-} \mathrm{B}$, while phosphate was determined in accor-dance with APHA 4500-P D and Stewart (1989). Chloride was determined titrimetrically in accordance with APHA $4500 \mathrm{Cl}^{-} \mathrm{B}$, ASTM D $512 \mathrm{~B}$ and D4458. This method required titration of an aliquot portion of the sample in the presence of potassium chromate and Volhard solution as indicators respectively to a brickred end point with silver nitrate.

Water samples were analyzed directly for fluoride using the ionselective electrode after mixing $30 \mathrm{ml}$ with $20 \mathrm{ml}$ acetate and $10 \mathrm{ml}$ citrate buffer. Aluminum was determined colourimetrically using UV4-100 Unicam UV/VIS spectrophotometer. This method involved formation of complexes with aluminon, eriochrome-cyanin $\mathrm{R}$, alizarin red $S$ and cathecol violet. Cyanide was determined titrimetrically in accordance with APHA $4500 \mathrm{CN}^{-} \mathrm{A}$ and D.
Magnesium, zinc, manganese, chromium and arsenic in water samples were determined spectrophotometrically in accordance with APHA 3111B, APHA 3111D, ASTM D3651 and ASTM D3974 using PerkinElmer AAnalyst 2000 Atomic Absorption Spectrophotometer (AAS). This method involved direct aspiration of the water sample into an air/acetylene flame in the presence of energy at specific wavelength generated by hollow cathode lamp peculiar only to the metal under investigation. Prior to analysis the AAS was calibrated with working standards of known concentrations to obtain a calibration curve for the individual metal. Samples were prepared in accordance with ASTM D5198/D3974 and ASTM D3976.

Analyses of total heterotrophic bacteria (THB), total heterotrophic fungi (THF), total coliform, thermotolerant coliform, E. coli, faecal streptococci, Salmonella and Shigella were as described by Akinde et al. (2011). Fungal cultures were observed while still on plates 
Table 2. The Mean Values \pm S.D. of Organoleptic and Physical Properties of the Raw Surface Water Samples from Obokun Rural Communities, Osun State, South-Western Nigeria.

\begin{tabular}{lcccccccc}
\hline Parameter & Lagodo 1 & Lagodo 2 & Odo Opo & Odo Gani & Odo Araba & Odo Elere & $\begin{array}{c}\text { WHO } \\
\text { Guidelines }\end{array}$ & $\begin{array}{c}\text { Nigerian } \\
\text { Standards }\end{array}$ \\
\hline $\mathrm{pH}$ & $6.0 \pm 0.10$ & $6.1 \pm 0.10$ & $6.9 \pm 0.10$ & $6.4 \pm 0.30$ & $6.2 \pm 0.20$ & $5.8 \pm 0.30$ & $6.5-8.5$ & $6.5-8.5$ \\
Colour, & Yes & Yes & Yes & Yes & Yes & Yes & - & \\
Odour & $\mathrm{O}^{*}$ & $\mathrm{O}$ & $\mathrm{O}$ & $\mathrm{O}$ & $\mathrm{O}$ & $\mathrm{O}$ & $\mathrm{U}^{\#}$ & $\mathrm{U}$ \\
Taste & $\mathrm{O}$ & $\mathrm{O}$ & $\mathrm{O}$ & $\mathrm{O}$ & $\mathrm{O}$ & $\mathrm{O}$ & $\mathrm{U}$ & $\mathrm{U}$ \\
Temperature $\left({ }^{\circ} \mathrm{C}\right)$ & $25.5 \pm 0.1$ & $25.4 \pm 0.06$ & $25.3 \pm 0.17$ & $24.7 \pm 0.17$ & $24.9 \pm 0.12$ & $25.0 \pm 0.15$ & - & Ambient \\
Conductivity $(\mu \mathrm{S} / \mathrm{cm})$ & $70.4 \pm 0.12$ & $73.1 \pm 0.12$ & $158.5 \pm 0.56$ & $180.3 \pm 2.08$ & $129.8 \pm 0.47$ & $162.3 \pm 0.49$ & - & 1,000 \\
Turbidity (NTU) & $40.6 \pm 1.04$ & $42.6 \pm 0.85$ & $96.2 \pm 0.60$ & $110.4 \pm 1.01$ & $79.1 \pm 0.60$ & $99.1 \pm 1.04$ & 5.0 & 5.0 \\
\hline
\end{tabular}

${ }^{*} \mathrm{O}$ - Objectionable, ${ }^{\#} \mathrm{U}$ - Unobjectionable,

and after wet mount in lacto-phenol on slides under the compound microscope (Obire et al., 2009). Observed characteristics were recorded and compared with the established identification key of Malloch (1997). Identification and characterization of all pathogenic bacterial isolates were done to species level on the basis of their cultural, morphological and physiological characteristics by the identification schemes and methods described by Cruickshank et al. (1975), Morgan et al. (1979), Watahiki et al. (1983), Olutiola et al. (1991), Barrow and Feltham (1993), Yumoto et al. (1998) and Yumoto et al. (2001).

The disc diffusion method was used in the determination of the susceptibility of the pathogenic isolates to various antibiotics. The stock culture was transferred into nutrient broth tubes and incubates at $37^{\circ} \mathrm{C}$ for $18-24 \mathrm{~h}$. To the gram negative plates, Mueller Hilton Agar (MHA) in plates were inoculated with the 18-24 $\mathrm{h}$ old culture isolate, after which the gram negative antibiotics multidisc (Abtek Biologicals, UK) labeled Nitrofurantoin $(300 \mu \mathrm{g})$, Oflaxacin $(30 \mu \mathrm{g})$, Gentamicin $(10 \mu \mathrm{g})$, Ceftazidime $(30 \mu \mathrm{g})$, Cefixime $(5 \mu \mathrm{g})$, Ciprofloxacin $(5 \mu \mathrm{g})$, Cefuroxime $(30 \mu \mathrm{g})$ and Augmentin $(30 \mu \mathrm{g})$ was aseptically placed at the centre of the plates using sterile forceps and incubated at $37^{\circ} \mathrm{C}$ for $18-24 \mathrm{~h}$. To the gram positive plates, the MHA media was inoculated with a swab full of the 18-24 $\mathrm{h}$ old broth culture, after which gram positive antibiotics multidisc (Abtek Biologicals, UK) labeled Ampicillin $(25 \mu \mathrm{g})$, Tetracycline (10 $\mu \mathrm{g})$, Penicillin $(10 \mu \mathrm{g})$, Streptomycin $(10 \mu \mathrm{g})$, Erythromycin $(5 \mu \mathrm{g})$, Chloramphenicol $(30 \mu \mathrm{g})$, Cloxacillin $(5 \mu \mathrm{g})$ and Gentamicin $(10 \mu \mathrm{g})$ was aseptically placed at the centre of the plates with the aid of sterile forceps and incubated at $37^{\circ} \mathrm{C}$ for $18-24 \mathrm{~h}$. Plates were examined for sensitivity of the organisms to the various antibiotics based on the size of their zones of inhibition. Isolates with zones of inhibition of $13 \mathrm{~mm}$ or less around the antibiotic disc were termed resistant while those above $13 \mathrm{~mm}$ were regarded as sensitive (Craven et al., 1977; Brown and Blowers, 1978; Phaneuf and Neu, 1979; Fass, 1982; Brumfitt et al., 1984).

In calculating statistic for acquired bacterial data from each surface water body, all enumerations were converted to $\log _{10}$ values and the calculations of the mean and standard deviation were completed on the transformed data using excel spreadsheet. This was followed by using the parametric approach as outline in Bartram and Rees (2000) to calculate the $95^{\text {th }}$ percentile (95\%ile) of the distribution by using the formula:

$\log _{10} 95 \%$ ile $=$ Arithmetic mean $\log _{10}$ bacterial concentration + (1.6449 $\times$ standard deviation of $\log _{10}$ bacterial concentration).

In order to establish relationship between the values obtained for total coliform, thermotolerant coliform and $E$. coli, Pearson correlation test was used. The statistical analysis was performed with SPSS 16.0 for Windows (SPSS Inc., Chicago, USA).

\section{RESULTS}

The mean values \pm standard deviation (S.D.) of the physical and organoleptic properties of the water samples are presented in Table 2. In situ $\mathrm{pH}$ ranged between $5.8 \pm 0.30$ and $6.9 \pm 0.10$ with the least mean value in Odo Elere and the highest mean value in Odo Opo. In situ temperature values ranged between $24.7 \pm 0.17$ and $25.5 \pm 0.1^{\circ} \mathrm{C}$ with the lowest value in Odo Araba and the highest value in Lagodo 1.

Light greenish brown colouration with objectionable musty odour and taste characterized most of the surface water bodies sampled for this study. This was corroborated with high turbidity (between 40.6 NTU and 110.4 NTU) observed in all the tested samples. These values were well above the acceptable limit of 5 NTU. In situ conductivity of the surface water samples ranged between $70.4 \pm 0.12$ and $180.3 \pm 2.08 \mu \mathrm{S} / \mathrm{cm}$. The lowest value was recorded in Lagodo 1 and highest in Odo Gani.

The result of the inorganic chemical parameters analyzed for all the six (6) water samples collected in triplicates from the study area are presented in Table 3.

Except for nitrate and magnesium, all measured chemical parameters were below their respective stipulated limits for WHO Guideline and NSDWQ. Nitrite and nitrate are examples of the chemicals from agricultural activities that may be of health significance in drinking water especially in rural communities. Nitrite was only detected in Lagodo 2 and Odo Elere with concentration of $0.01 \mathrm{mg} / \mathrm{l}$ which is well below the $0.2 \mathrm{mg} / \mathrm{l}$ limit specified by NSDWQ (SON, 2007). Nitrate values ranged between 50 and $155 \mathrm{mg} / \mathrm{l}$ while magnesium constituent is in the range of 20 and $110 \mathrm{mg} / \mathrm{l}$.

Although no standard has been set for phosphate level in drinking water, however, very low amount of phosphate was present in all the natural water samples $(0.01-0.14$ $\mathrm{mg} / \mathrm{l})$. Chloride concentrations in excess of $250 \mathrm{mg} / \mathrm{l}$ are increasingly likely to be detected by taste, but some consumers may become accustomed to low levels of chloride-induced taste (WHO, 2011). Chloride values of between 15 and $28 \mathrm{mg} / \mathrm{l}$ recorded for all the water samples are far below the stipulated $250 \mathrm{mg} / \mathrm{l}$ limit. Geogenic 
Table 3. The Mean Values \pm S.D. of the inorganic constituents of the raw water samples.

\begin{tabular}{lcccccccc}
\hline Parameter (mg/l) & Lagodo 1 & Lagodo 2 & Odo Opo & Odo Gani & Odo Araba & Odo Elere & WHO Guidelines $^{\#}$ & NSDWQ* $^{*}$ \\
\hline Nitrite & $<0.01$ & $0.01 \pm 0.00$ & $<0.01$ & $<0.01$ & $<0.01$ & $0.01 \pm 0.00$ & 3 & 0.2 \\
Nitrate & $78 \pm 1.73$ & $53 \pm 2.89$ & $50 \pm 1.00$ & $52 \pm 0.58$ & $155 \pm 5.86$ & $50 \pm 1.00$ & 50 & 50 \\
Phosphate & $0.01 \pm 0.00$ & $0.02 \pm 0.01$ & $0.04 \pm 0.01$ & $0.01 \pm 0.00$ & $0.02 \pm 0.00$ & $0.14 \pm 0.02$ & No Limit & No Limit \\
Chloride & $23 \pm 1.15$ & $15 \pm 1.73$ & $18 \pm 0.58$ & $20 \pm 1.53$ & $24 \pm 3.61$ & $28 \pm 3.46$ & 250 & 250 \\
Fluoride & $1.00 \pm 0.00$ & $0.98 \pm 0.03$ & $1.00 \pm 0.00$ & $0.26 \pm 0.03$ & $0.74 \pm 0.02$ & $0.94 \pm 0.01$ & 1.5 & 1.5 \\
Aluminum & $0.02 \pm 0.02$ & $<0.01$ & $<0.01$ & $0.10 \pm 0.00$ & $<0.01$ & $0.30 \pm 0.06$ & 0.2 & 0.2 \\
Cyanide & $<0.01$ & $<0.01$ & $<0.01$ & $<0.01$ & $<0.01$ & $<0.01$ & 0.07 & 0.01 \\
Magnesium & $58 \pm 6.56$ & $110 \pm 11.53$ & $20 \pm 0.58$ & $77 \pm 3.00$ & $63 \pm 3.21$ & $76 \pm 2.65$ & 0.2 & 0.2 \\
Zinc & $<0.01$ & $<0.01$ & $0.10 \pm 0.00$ & $<0.01$ & $<0.01$ & $0.07 \pm 0.01$ & 3.0 & 3.0 \\
Manganese & $<0.01$ & $<0.01$ & $<0.01$ & $<0.01$ & $<0.01$ & $0.01 \pm 0.00$ & 0.1 & 0.2 \\
Chromium VI & $<0.01$ & 0.01 & $<0.01$ & $<0.01$ & $0.01 \pm 0.01$ & $0.04 \pm 0.01$ & 0.05 & 0.05 \\
Arsenic & $<0.01$ & $<0.01$ & $<0.01$ & $<0.01$ & $<0.01$ & $<0.01$ & 0.01 & 0.01 \\
\hline
\end{tabular}

"WHO (2011); * SON (2007).

contaminants of health significance such as fluoride, aluminium, cyanide, chromium and arsenic in the water samples are only available in negligible quantities that are their concentrations were below the equipment detection limit of $0.01 \mathrm{mg} / \mathrm{l}$.

The average counts \pm S.D. as well as summary statistics (sample number, $\log _{10}$ median and $\log _{10} 95 \%$ ile) of THB, THF and pathogenic bacteria in the surface water samples from rural communities in Obokun are presented in Table 4. Values were then compared with the WHO Guideline and NSDWQ.

All the surface water samples contained THB (1100 $5900 \mathrm{cfu} / \mathrm{ml})$ and total coliforms $(9.00-78.0 \mathrm{cfu} / 100 \mathrm{ml})$ above their respective $100 \mathrm{cfu} / \mathrm{ml}$ and $10 \mathrm{cfu} / 100 \mathrm{ml}$ tolerant levels. THF was also found in the range of $1.00-7.00$ $\mathrm{cfu} / \mathrm{ml}$. All of the samples (100\%) contained thermotolerant coliform (4.0 - $11.0 \mathrm{cfu} / 100 \mathrm{ml})$, Escherichia coli $(4.00$ $7.00 \mathrm{cfu} / 100 \mathrm{ml})$, faecal streptococci $(1.00-5.00 \mathrm{cfu} / 100 \mathrm{ml})$ and Salmonella $1.00-8.00 \mathrm{cfu} / 100 \mathrm{ml}$ while $67 \%$ contained Shigella $(1.00-6.00 \mathrm{cfu} / 100 \mathrm{ml})$.

Presence of $E$. coli with between 4 and $7 \mathrm{cfu} / 100 \mathrm{ml}$ numbers suggest that all the surface water catchments may be exposed to faecal contamination. Odo Gani had the highest counts of Faecal streptococci with a value of $5 \mathrm{cfu} / 100 \mathrm{ml}$ while Lagodo 2, Odo Araba and Odo Elere had the lowest concentration ( $1.00 \mathrm{cfu} / 100 \mathrm{ml})$.

The bacterial species with pathogenic potential isolated from the surface water samples include Pseudomonas aeruginosa, Salmonella typhi, Shigella flexneri, Corynebacterium ulcerans and E. coli. Salmonella species were present in all the samples with numbers ranging between 1 to $8 \mathrm{cfu} / 100 \mathrm{ml}$. Lowest Shigella count was recorded for Odo Araba $(1.0 \mathrm{cfu} / 100 \mathrm{ml})$ while the highest value was recorded for Odo Elere $(6.0 \mathrm{cfu} / 100$ $\mathrm{ml})$. Shigella species were not isolated in Lagodo River (both sample points 1 and 2). It is clearly evident that all the six (6) surface water samples had measured microbiology parameters above the specified WHO Guideline and NSDWQ.

The Minimum Inhibitory Concentration (MIC) and the antibiogram of the pathogenic isolates with respect to various Gram negative and Gram positive antibiotics are listed in Table 5. The antibiogram revealed that all the isolated Gram negative pathogenic bacteria were sensitive to Ofloxacin $(30 \mu \mathrm{g})$ and Ciprofloxacin $(5 \mu \mathrm{g})$. About $80 \%$ of the isolates were sensitive to Gentamicin $(10 \mu \mathrm{g})$ while $60 \%$ were sensitive to Nitrofurantoin $(300 \mu \mathrm{g})$ and Cefixime $(5 \mu \mathrm{g})$. They were all resistant to Ceftazidime $(30 \mu \mathrm{g})$, Cefuroxime $(30 \mu \mathrm{g})$ and Augmentin $(30 \mu \mathrm{g})$. The Gram positive $C$. ulcerans isolated showed multiple-resistant to more than two classes of antibiotics. It was resistant to Ampicillin ( $\beta$-lactams, $25 \mu \mathrm{g})$, Tetracycline $(10 \mu \mathrm{g})$, Penicillin $(10 \mu \mathrm{g})$, Erythromycin (macrolide, $5 \mu \mathrm{g}$ ) and Cloxacillin $(5 \mu \mathrm{g})$.

\section{DISCUSSION}

The acceptability and use of any water catchment for drinking, recreation and other domestic needs are influenced by certain physico-chemical and microbiological attributes which are guided by the World Health Organization and other related agencies. The results of the analyzed physico-chemical and microbiological parameters of the study surface water samples were correlated with those of the World Health Organization (WHO, 2011) and related agency in Nigeria (SON, 2007).

Except for Odo-Opo, with the mean pH value of $6.9 \pm$ 0.10 , all mean $\mathrm{pH}$ values were below the WHO Guideline and NSDWQ pH range of $6.5-8.5$ for drinking water at ambient temperature (SON, 2007; WHO 2011). In situ pH range of $5.8 \pm 0.30-6.9 \pm 0.10$ and mean temperature range of $24.7 \pm 0.17-25.5 \pm 0.1^{\circ} \mathrm{C}$ obtained for the surface water samples in this study is typical of surface water from natural catchments in tropical Nigeria (Agbogu et al., 2006; Abu and Egenonu, 2008; Kolawole et al., 2011). Although $\mathrm{pH}$ and temperature in drinking water 
Table 4. Average Counts \pm S.D. of Heterotrophs and Pathogenic Bacteria in Surface Water Samples.

\begin{tabular}{|c|c|c|c|c|c|c|c|c|}
\hline \multirow{2}{*}{ Sample ID } & THB & THF & Total coliform & Ther coliform ${ }^{\#}$ & E. coil & Faecal streps & Salmonella & Shigella \\
\hline & \multicolumn{2}{|c|}{ cfu/ml } & \multicolumn{6}{|c|}{ cfu/100 ml } \\
\hline \multirow{2}{*}{ Lagodo 1} & $1800 \pm 0.05^{\star}$ & $1.00 \pm 0.00$ & $63 \pm 0.02$ & $9.00 \pm 0.08$ & $5.00 \pm 0.04$ & $3.00 \pm 0.00$ & $6.00 \pm 0.07$ & $0.00 \pm 0.00$ \\
\hline & $6(3.27,3.36)^{\star *}$ & $6(0.00,0.00)$ & $6(1.81,1.83)$ & $6(1.00,1.13)$ & $6(0.70,0.77)$ & $6(0.48,0.48)$ & $6(0.78,0.89)$ & $6(0.00,0.00)$ \\
\hline \multirow{2}{*}{ Lagodo 2} & $1100 \pm 0.08$ & $7.00 \pm 0.09$ & $78 \pm 0.01$ & $11 \pm 0.04$ & $6.00 \pm 0.04$ & $1.00 \pm 0.00$ & $6.00 \pm 0.11$ & $0.00 \pm 0.00$ \\
\hline & $6(3.06,3.19)$ & $6(0.78,0.93)$ & $6(1.89,1.91)$ & $6(1.04,1.10)$ & $6(0.78,0.85)$ & $6(0.00,0.00)$ & $6(0.70,0.87)$ & $6(0.00,0.00)$ \\
\hline \multirow{2}{*}{ Odo Opo } & $1700 \pm 0.06$ & $1.00 \pm 0.00$ & $9.00 \pm 0.03$ & $4.00 \pm 0.10$ & $4.00 \pm 0.06$ & $2.00 \pm 0.09$ & $1.00 \pm 0.00$ & $3.00 \pm 0.00$ \\
\hline & $6(3.22,3.31)$ & $6(0.00,0.00)$ & $6(0.95,1.00)$ & $6(0.60,0.77)$ & $6(0.60,0.71)$ & $6(0.30,0.45)$ & $6(0.00,0.00)$ & $6(0.48,0.48)$ \\
\hline \multirow{2}{*}{ Odo Gani } & $2800 \pm 0.04$ & $1.00 \pm 0.00$ & $14 \pm 0.06$ & $6.00 \pm 0.11$ & $5.00 \pm 0.05$ & $5.00 \pm 0.04$ & $4.00 \pm 0.10$ & $3.00 \pm 0.14$ \\
\hline & $6(3.45,3.51)$ & $6(0.00,0.00)$ & $6(1.18,1.27)$ & $6(0.70,0.87)$ & $6(0.70,0.78)$ & $6(0.70,0.77)$ & $6(0.60,0.77)$ & $6(0.48,0.70)$ \\
\hline \multirow{2}{*}{ Odo Araba } & $5900 \pm 0.04$ & $1.00 \pm 0.16$ & $23 \pm 0.03$ & $9.00 \pm 0.07$ & $7.00 \pm 0.14$ & $1.00 \pm 0.00$ & $2.00 \pm 0.27$ & $1.00 \pm 0.16$ \\
\hline & $6(3.75,3.81)$ & $6(0.00,0.26)$ & $6(1.36,1.40)$ & $6(0.90,1.02)$ & $6(0.78,1.01)$ & $6(0.00,0.00)$ & $6(0.30,0.74)$ & $6(0.00,0.26)$ \\
\hline \multirow{2}{*}{ Odo Elere } & $1800 \pm 0.08$ & $1.00 \pm 0.16$ & $24 \pm 0.08$ & $9.00 \pm 0.11$ & $6.00 \pm 0.08$ & $1.00 \pm 0.16$ & $8.00 \pm 0.22$ & $6.00 \pm 0.31$ \\
\hline & $6(3.27,3.39)$ & $6(0.00,0.26)$ & $6(1.40,1.53)$ & $6(0.90,1.08)$ & $6(0.85,0.97)$ & $6(0.00,0.26)$ & $6(0.90,1.26)$ & $6(0.85,1.36)$ \\
\hline WHO Limits & 100 & 0 & 10 & 0 & 0 & 0 & 0 & 0 \\
\hline $\begin{array}{l}\text { NSDWQ } \\
\text { Limits }\end{array}$ & - & - & 10 & 0 & 0 & 0 & 0 & 0 \\
\hline
\end{tabular}

"Thermotolerant coliform; * mean count \pm standard deviation (S.D); ${ }^{* *}$ sample number ( Log $_{10}$ Median, Log $_{10}$ 95\%ile).

Table 5. Minimum inhibitory concentration $(\mathrm{mm})$ and antibiogram of pathogenic Isolates

\begin{tabular}{|c|c|c|c|c|c|c|c|c|c|}
\hline ID & Isolate & NIT & OFL & GEN & CAZ & CXM & CPR & CRX & AUG \\
\hline P1 & $\begin{array}{l}\text { Pseudomonas } \\
\text { aeruginosa }\end{array}$ & $\begin{array}{c}24 \pm 1.73 \\
\text { (S) }\end{array}$ & $\begin{array}{l}30 \pm 2.00 \\
\text { (S) }\end{array}$ & $\begin{array}{c}16 \pm 1.00 \\
(S)\end{array}$ & $\begin{array}{c}9 \pm 1.73 \\
(R)\end{array}$ & $\begin{array}{c}18 \pm 3.00 \\
(\mathrm{~S})\end{array}$ & $\begin{array}{l}30 \pm 5.57 \\
\text { (S) }\end{array}$ & $\begin{array}{c}7 \pm 0.00 \\
(R)\end{array}$ & $\begin{array}{c}6 \pm 0.00 \\
(R)\end{array}$ \\
\hline P2 & Salmonella typhi & $\begin{array}{l}28 \pm 5.29 \\
(S)\end{array}$ & $\begin{array}{c}30 \pm 2.00 \\
(\mathrm{~S})\end{array}$ & $\begin{array}{c}25 \pm 2.65 \\
(S)\end{array}$ & $\begin{array}{c}8 \pm 2.00 \\
(R)\end{array}$ & $\begin{array}{l}23 \pm 1.00 \\
(\mathrm{~S})\end{array}$ & $\begin{array}{c}36 \pm 5.29 \\
(\mathrm{~S})\end{array}$ & $\begin{array}{c}13 \pm 1.73 \\
(\mathrm{R})\end{array}$ & $\begin{array}{c}7 \pm 1.00 \\
(R)\end{array}$ \\
\hline P4 & Shigella flexneri & $\begin{array}{c}21 \pm 2.65 \\
(\mathrm{~S})\end{array}$ & $\begin{array}{l}30 \pm 4.36 \\
(\mathrm{~S})\end{array}$ & $\begin{array}{c}15 \pm 1.00 \\
(\mathrm{~S})\end{array}$ & $\begin{array}{c}6 \pm 0.00 \\
(R)\end{array}$ & $\begin{array}{c}13 \pm 4.00 \\
(R)\end{array}$ & $\begin{array}{c}34 \pm 3.00 \\
(S)\end{array}$ & $\begin{array}{c}5 \pm 0.00 \\
(R)\end{array}$ & $\begin{array}{c}6 \pm 2.00 \\
(R)\end{array}$ \\
\hline P5 & Shigella flexneri & $\begin{array}{c}13 \pm 2.65 \\
(R)\end{array}$ & $\begin{array}{c}22 \pm 2.65 \\
(\mathrm{~S})\end{array}$ & $\begin{array}{c}15 \pm 0.00 \\
(\mathrm{~S})\end{array}$ & $\begin{array}{c}10 \pm 2.65 \\
(R)\end{array}$ & $\begin{array}{l}25 \pm 1.00 \\
(\mathrm{~S})\end{array}$ & $\begin{array}{c}27 \pm 4.36 \\
(S)\end{array}$ & $\begin{array}{c}7 \pm 0.00 \\
(R)\end{array}$ & $\begin{array}{c}7 \pm 1.73 \\
(R)\end{array}$ \\
\hline P6 & Escherichia coli & $\begin{array}{c}12 \pm 2.65 \\
(\mathrm{R})\end{array}$ & $\begin{array}{c}22 \pm 2.65 \\
(\mathrm{~S})\end{array}$ & $\begin{array}{c}12 \pm 3.00 \\
(R)\end{array}$ & $\begin{array}{c}9 \pm 2.00 \\
(\mathrm{R})\end{array}$ & $\begin{array}{c}12 \pm 0.00 \\
(R)\end{array}$ & $\begin{array}{c}30 \pm 4.36 \\
(\mathrm{~S})\end{array}$ & $\begin{array}{c}10 \pm 2.65 \\
(\mathrm{R})\end{array}$ & $\begin{array}{c}8 \pm 2.65 \\
(R)\end{array}$ \\
\hline & & AMP & TET & PEN & STR & ERY & CHL & CXC & GEN \\
\hline P3 & $\begin{array}{l}\text { Corynebacterium } \\
\text { ulcerans }\end{array}$ & $\begin{array}{c}6 \pm 0.00 \\
(R)\end{array}$ & $\begin{array}{c}10 \pm 2.65 \\
(R)\end{array}$ & $\begin{array}{c}7 \pm 0.00 \\
(R)\end{array}$ & $\begin{array}{c}16 \pm 1.73 \\
(\mathrm{~S})\end{array}$ & $\begin{array}{c}10 \pm 0.00 \\
(R)\end{array}$ & $\begin{array}{c}15 \pm 2.65 \\
(S)\end{array}$ & $\begin{array}{c}8 \pm 1.73 \\
(R)\end{array}$ & $\begin{array}{c}15 \pm 2.65 \\
\text { (S) }\end{array}$ \\
\hline
\end{tabular}


Table 5. Contd.

\begin{tabular}{llcccccc}
\hline & \multicolumn{3}{c}{ Gram Negative antibiotics } & \multicolumn{3}{c}{ Gram Positive antibiotics } \\
NIT & $\begin{array}{l}\text { Nitrofurantoin }(300 \\
\mu \mathrm{g})\end{array}$ & CXM & Cefixime $(5 \mu \mathrm{g})$ & AMP & $\begin{array}{c}\text { Ampicillin } \\
(25 \mu \mathrm{g})\end{array}$ & ERY & Erythromycin $(5 \mu \mathrm{g})$ \\
OFL & Ofloxacin $(30 \mu \mathrm{g})$ & CPR & Ciprofloxacin $(5 \mu \mathrm{g})$ & TET & $\begin{array}{c}\text { Tetracyclin } \\
\text { e }(10 \mu \mathrm{g})\end{array}$ & $\mathrm{CHL}$ & Chloramphenicol $(30 \mu \mathrm{g})$ \\
GEN & Gentamicin $(10 \mu \mathrm{g})$ & CRX & Cefuroxime $(30 \mu \mathrm{g})$ & PEN & $\begin{array}{c}\text { Penicillin } \\
(10 \mu \mathrm{g})\end{array}$ & CXC & Cloxacillin $(5 \mu \mathrm{g})$ \\
CAZ & Ceftazidime $(30 \mu \mathrm{g})$ & AUG & Augumentin $(30 \mu \mathrm{g})$ & STR & $\begin{array}{c}\text { Streptomy } \\
\text { cin }(10 \mu \mathrm{g})\end{array}$ & GEN & Gentamicin $(10 \mu \mathrm{g})$ \\
\hline
\end{tabular}

usually have no direct impact on consumers, they are equally regarded as important operational water quality parameters. For example, elevated water temperature enhances the growth of microorganisms and may increase problems related to taste, odour, colour and corrosion (WHO, 2011).

Conductivity is useful as a general measure of salinity or to estimate the amount of dissolved solids (Richard, 1954; Obiefuna and Sheriff, 2011). It increases as the amount of dissolved mineral (ions) increases. Significant changes in conductivity could then be an indicator that a discharge or some other source of pollution has entered a surface water system. The maximum conductivity concentration in this study was $180.3 \pm 2.08 \mu \mathrm{S} / \mathrm{cm}$ which is below the NSDWQ value of $1,000 \mu \mathrm{S} / \mathrm{cm}$. Chinedu et al. (2011) reported an average conductivity concentration of $97.3 \pm 1.1 \mu \mathrm{S} / \mathrm{cm}$ in similar surface water body in South-Western Nigeria.

High level of turbidity is a secondary drinking water standard and therefore is regulated because it is more of an aesthetic rather than a health hazard. Turbidity in excess of 5 NTU as observed in this study (40.6 NTU - 110.4 NTU) may be noticeable and consequently objectionable to consumers (WHO, 1985). Elevated turbidity values in surface water in Nigeria have also been reported by various authors as a direct consequence of run-off effects as well as domestic and industrial activities on the surface water bodies (Ajibade, 2004, Adefemi et al., 2007 and Wakawa et al., 2008). High turbidity in drinking water sources has the tendency to interfere with the efficiency of disinfection.

Observed colour as well as the objectionable odour and taste of all the surface water samples in the study area may not be unconnected with the geology or the mineralogy of the soil and sediment in the study area (Oluyemi et al., 2010; Ayoade and lbitoye, 2012). This could be attributed to the presence of organic matter for example humic substances as well as metals such as iron and manganese (WHO, 1985; Young et al., 1996). For example, several studies have reported high iron (Fe) content in surface water catchments in South-Western Nigeria (Oluyemi et al., 2010; Ayoade and Ibitoye, 2012). Oluyemi et al. (2010) concluded that waters from southwest region in Nigeria may have taste and aesthetic problems. Although it is desirable that drinking water should be colourless, odourless and tasteless, the rural people usually have limited options and will just have to adapt to the available drinking water catchments within their locality.

Although most of the inorganic chemical constituents of the raw water samples are typical of natural freshwater bodies in tropical environment (Stewart, 1989) and are also within their various acceptable limits for potability, parameters such as nitrate and magnesium are well above the respective stipulated standards of 50 and 0.2 $\mathrm{mg} / \mathrm{l}$. High nitrate concentration might be attributed to the agricultural activities in the area (Punmia et al., 1998; Adekunle et al., 2007). While excessive nitrate in drinking water can cause cyanosis and asphyxia (blue-baby syndrome) in infants less than three (3) months old, high concentration of magnesium can only reduce acceptability of the water by the consumers (WHO, 2011).

The assessment of microbiological quality of water from different sources was essential for detecting the presence or absence of organisms that might constitute health hazards in water, which could be used as a guide to monitor and protect the water catchments (Ajayi and Adejumo, 2011).

THB are naturally occurring bacteria which are accustomed to growth even in very nutrient-poor environment. Spring-fed natural water systems are most vulnerable to microbial contamination. 
Elevated concentrations of THB in all the water samples tested could also be attributed to high turbidity. Most heterotrophic bacteria (THB) in drinking water are not human pathogens and are therefore of little or no human health consequence. Under some circumstances, however, opportunistic pathogens within the heterotrophic flora can constitute a health risk for immunocompromised individuals, including the very young (Culp, 1969; Lowbury et al., 1970).

The THB range of $1100-5900 \mathrm{cfu} / \mathrm{ml}$ obtained in the surface water samples which exceeded the WHO Guideline and NSDWQ value of $100 \mathrm{cfu} / \mathrm{ml}$ indicated clearly that the water samples are of questionable quality. High microbial load have been reported for various drinking water catchments in similar environments in Nigeria (Ajayi and Adejumo, 2011). Poor waste disposal methods and sanitation practices in most part of the country could be partly responsible for high THB values in drinking water catchments in Nigeria.

The mean concentrations of THF are in the range of 1.00 and $7.00 \mathrm{cfu} / \mathrm{ml}$ in the tested surface water samples while Aspergillus, Candida, Penicilliumand Saccharomyces were the observed associated fungal genera. Observed fungal genera are consistent with those isolated by Obire et al. (2009) from surface water samples in similar tropical environment. Obire et al. (2009) had reported the presence of THF in drinking surface water catchments in Port Harcourt, South-Southern Nigeria with an arithmetic mean of $1130 \mathrm{cfu} / \mathrm{ml}$. They concluded that most of the isolated fungal genera which include Aspergillus, Byssochlamys, Candida, Cephalosporium, Cladosporium, Fusarium, Mucor, Penicillium, Rhizopus, Saccharomyces, Sporobolomyces, and Trichoderma are capable of causing chronic illnesses in humans upon ingestion of contaminated water.

Faecal indicator organisms are used to monitor the microbial quality of drinking water (Crauu, 1986). Coliform bacteria are a commonly used bacterial indicator of water pollution, although not always the actual cause of disease (Schueler et al., 2000). Presence of coliform bacteria including thermotolerant group further revealed the poor quality of the water samples. Isolation of opportunistic bacteria with pathogenic potential comprising $P$. aeruginosa, $S$. typhi, S. flexneri, C. ulcerans and E. coli is an indication that the rural people are at risk of water-borne disease outbreaks.

Presence of potential pathogens might be the result of observed human activities in and around the water bodies. Except for Odo Elere, where the almost stagnant pool was reserved for drinking, ongoing activities around other surface water bodies include bathing, laundry, washing of farm produce and food processing. It was also noted that most of the houses in the study area do not have proper sanitary facilities; open defaecation in nearby bushes close to water catchments is a common practice. Water run-off from the soil could then increase the population dynamics and species diversity of potential pathogens in the recipient surface waters.

Although Chinedu et al. (2011) who conducted similar studies in Canaanland, Ota, South-Western Nigeria did not check the microbiological quality of the analyzed surface water samples, they however concluded based on the evidence of high turbidity, total dissolved solids (TDS) and biological oxygen demand (BOD) that the water might be contaminated and therefore not fit for drinking purposes by the inhabitants.

An antibiogram study of $P$. aeruginosa, S. typhi, S. flexneri and $E$. coli showed that they were all resistant to Ceftazidime $(30 \mu \mathrm{g})$, Cefuroxime $(30 \mu \mathrm{g})$ and Augmentin $(30 \mu \mathrm{g})$ while some of the isolates still demonstrated resistance to one or more other antibiotics. Similarly, $C$. ulcerans, the only isolated gram positive bacteria showed resistance to five out of eight antibiotics tested (Table 5). The experimental results therefore suggested that multidrug resistance by environmental bacteria is on the increase and could pose a serious health threat to the users of the water from these rivers. These bacterial isolates will also be a great concern in health and medicine.

\section{Conclusion}

This work has therefore revealed that surface water samples obtained within six (6) rural communities in Obokun LGA did not meet both local and international requirements for drinking water quality and therefore not fit for human consumption. This work corroborates the assertion of Fasunwon et al. (2008) credited to the conclusion of a joint UNICEF/WHO 2005 report on rapid assessment of drinking water quality in Nigeria. They stated that more than $70 \%$ of water sources in Nigeria are contaminated and constitute risks to human health. Extensive work is hereby required to check for the presence of highly virulent strains of $P$. aeruginosa, $S$. typhi, S. flexneri, $C$. ulcerans and $E$. coli in Obokun rural communities. The work should be targeted at using modern molecular techniques to determine the pathogenicity of the isolates and their possession of extra chromosomal plasmid materials.

Further interactions with the selected members of the investigated Obokun rural communities revealed that few households practice some form of local drinking water purification by boiling, filtration, exposure to sunlight and use of moringa seed. To them, these methods have been assisting in reducing microbial contaminants and other hazardous side-effects. However, studies are ongoing in our laboratory to test the efficacy of their claims as to determine whether this would lead to development of cost-effective local treatment techniques for sustainable use of the surface water resource.

\section{ACKNOWLEDGEMENTS}

The authors acknowledge the Rural Water and Environmental Sanitation Authority (RUWESA), Osun State Government Secretariat, Osun State, Nigeria for physico- 
chemical analysis of water samples. We also appreciate Dr Declan Page of CSIRO Land and Water - Waite Campus, Australia and Dr. W. F. Sule of the Department of Biological Sciences, Osun State University, Osogbo, Nigeria for the careful review of this manuscript.

\section{REFERENCES}

Abu GO, Egenonu C (2008). The current pollution status of the new Calabar River in the Niger Delta region of Southern Nigeria: A survey of antibiogram profiles of its bacterial isolates. Afr. J. Environ. Sci. Tech. 2(6): 134-141.

Adefemi OS, Asaolu SS, Olaofe O (2007). Assessment of the physico-chemical status of water samples from major dams in Ekiti State, Nigeria. Pak. J. Nutr. 6(6): 657-659.

Adekunle IM, Adetunji MT, Gbadebo AM, Banjoko OB (2007) Assessment of groundwater quality in a typical rural settlement in Southwest Nigeria. Int. J. Environ. Res. Public Health 4(4): $307-$ 318

Agbaire PO, Obi CG (2009). Seasonal variations of some physicochemical properties of River Ethiope water in Abraka, Nigeria. J. Appl. Sci. Environ. Manage. 13(1): 55-57.

Agbogu VN, Umoh VJ, Okuofu CA, Ameh JB, Smith SI (2006). Study of the bacteriological and physicochemical indicators of pollution of surface waters in Zaria, Nigeria. Afr. J. Biotechnol. 5(9): $732-737$.

Ajayi OA, Adejumo TO (2011). Microbiological assessment and some physico-chemical properties of water sources in AkungbaAkoko, Nigeria. J. Toxicol. Env. Health Sci. 3(13): 342-346.

Ajibade LT (2004). Assessment of water quality near River Asa, Ilorin, Nigeria. The Environmentalist 24(1): 11-18.

Akinde SB, Nwachukwu MI, Ogamba AS (2011). Storage effects on the quality of sachet water produced within Port Harcourt metropolis, Nigeria. Jordan J. Biol. Sci. 4 (3): 157-164.

APHA (1998). Standard methods for the examination of water and wastewater. $20^{\text {th }}$ edition, American Public Health Association, American Water Works Association and Water Environment Federation. USA. ISBN 0-87553-235-7, ISSN 55-1979.

ASTM (1999). Water and environmental technology. Annual book of ASTM standards. American Society for Testing and Materials, Philadelphia. Section 11: 01-05, ISBN 0-8031-2686-7.

Ayoade PA, Ibitoye TA (2012) Appraisal of water quality status within Ilesha environs, South-Western Nigeria. J. Emerg. Trends. Eng. Appl. Sci. 3(6): 969-976.

Barrow GL, Feltham RKA (1993). Cowan and Steel's manual for the identification of medical bacteria. $3^{\text {rd }}$ edition. Cambridge University Press, Cambridge, UK. pp. 331.

Bartram J, Rees G, ed. (2000). Monitoring bathing waters: a practical guide to the design and implementation of assessments and monitoring programmes. London, E and FN Spon. Published on behalf of the World Health Organization, Commission of the European Communities and US Environmental Protection Agency, ISBN 0-419-24390-1.

Brown D, Blowers R (1978). Disc methods of sensitivity testing and other semiquantitative methods. In: Reeves DS, Phillips I, Williams JD, Wise R (eds) Laboratory methods in antimicrobial chemotherapy. Churchill Livingstone, Edinburgh, pp 8-30.

Brumfitt W, Hamilton-Miller JMT, Gooding A (1984). Importance of methodology in determining bactericidal and bacteriostatic activities of azlocillin and ticarcillin against Pseudomonas aeruginosa. J. Med. Microbiol. 17: 37-44.

Chima GN, Okpe VC (2008). Water quality in Nsukka area of Southeastern Nigeria. J. Environ. 2(1): 35-42.

Chinedu SN, Nwinyi OC, Oluwadamisi AY, Eze VN (2011). Assessment of water quality in Canaanland, Ota, Southwest Nigeria. Agric. Biol. J. N. Am. 2(4): 577-583.
Crauu GF (1986). Water borne diseases in United States; CRC, Press Boca Rato. Florida. 295.

Craven PC, Jorgensen JH, Kaspar RL, Drutz DJ (1977). Amikacin therapy of patients with multiply antibiotic-resistant Serratia marcescens infections. Am. J. Med. 62(6): 902-910.

Cruickshank R, Duguid JP, Marmion BP, Swain RHA (1975). Medical Microbiology. $12^{\text {th }}$ edition, Vol. 2, Churchill Livingstone, Longman Group Limited, USA. ISBN 0443011117.

Culp RL (1969). Disease due to "non-pathogenic" bacteria. J. Am. Water Works Assoc. 61: 157.

Decker EH, Elliot S, Smith FA (2002). Megacities and the environment. Sci. World J. 2: 374-386.

Fadare SO, Olawuni PO (2008). Domestic water supply and health of households in the three residential densities in Osogbo, Osun State, Nigeria. Ethiop. J. Environ. Studies Mgt. 1 (2): 35-43.

Fass RJ (1982). Quality control and interpretive criteria for the azlocillin disk diffusion susceptibility test. Antimicrob. Agents Chemother. 22: 28-31.

Fasunwon O, Olowofela J, Akinyemi O, Fasunwon B, Akintokun O (2008). Contaminants evaluation as water quality indicator in Ago-Iwoye, South-western, Nigeria. Afr. Phys. Rev. 2: 110-116.

Kolawole OM, Ajayi KT, Olayemi AB, Okoh Al (2011). Assessment of water quality in Asa River (Nigeria) and its indigenous Clarias gariepinus fish. Int. J. Ennviron. Res. Public Health 8: 4332-4352.

Lowbury EJT, Thorn BT, Lilly HA, Babb JR, Whitall K. (1970). Sources of infection with Pseudomonas aeruginosa in patients with tracheostomy. J. Med. Microbiol. 3: 39-56.

Malloch D (1997). "How molds are grown," in: Malloch, D., Moulds: isolation, cultivation, identification, Department of Botany, University of Toronto, http://www. botany.utoronto.ca/ResearchLabs/MallochLab/Malloch/Moulds/Cultivation.html.

Morgan FJ, Adams KR, Priest FG (1979). A cultural method for the detection of pullulan-degrading enzymes in bacteria and its application to the genus Bacillus. J. Appl. Bacteriol. 46: 291-294.

NICOCUSA (2013) Osun State of Nigeria. Nigerian Chamber of Commerce USA, http://www.ncocusa.com/constituencies_osun.html. Assessed on August 5, 2013.

Obiefuna GI, Sheriff A (2011). Assessment of shallow ground water quality of Pindiga Gombe Area, Yola Area, NE, Nigeria for irrigation and domestic purposes. Res. J. Environ. Earth Sci. 3(2): 131-141.

Obire O, Barade WN, Putheti RR (2009). Physicochemical and mycological quality of a drinking water. e-J. Sci. Technol. 4(1): 11-16.

Olutiola PO, Famurewa O, Sonntag HG (1991). An introduction to general microbiology: A practical approach. 1st edition, Germany, Hyginene - Institut Der Universitat Heidelberg, pp. 267 ISBN 389426-042-4.

Oluyemi EA, Adekunle AS, Adenuga AA, Makinde WO (2010). Physico-chemical properties and heavy metal content of water sources in Ife North Local Government Area of Osun State, Nigeria. Afr. J. Environ. Sci. Technol. 4(10): 691-697.

Phaneuf D, Neu HC (1979). Agar disk diffusion susceptibility characteristics of azlocillin, carbenicillin, mezlocillin, piperacillin and ticarcillin. Antimicrob. Agents Chemother. 16:625-630.

Punmia BC, Jain AK, Jain AK (1998). Wastewater engineering. $2^{\text {nd }}$ Edition, Laxmi Publications (P) Ltd, New Delhi. pp. 660. ISBN: 978-81-318-0596-1.

Richard LA (1954). Diagnosis and improvement of saline and alkali soils. Agric Handbook, 60, USDA and IBH Pub. Coy Ltd., New Delhi, India, pp: 98-99.

Schueler R, Straub TM, Chandler DP (2000). Towards a unified system for detecting waterborne pathogens. J. Microbiol. Method. 53(2): 185-197.

SON (2007). Nigerian Standard for Drinking Water Quality. Standards Organization of Nigeria NIS 554: 2007; ICS 13.060.20. p 30.

Stewart EA (1989). Chemical analysis of ecological materials. $2^{\text {nd }}$ 
edition. Blackwell scientific publications. London. pp. 368. ISBN 0-632-01742-2.

Tchobanoglous G, Burton FL, Stensel HD (2003). Wastewater Engineering (Treatment Disposal Reuse) / Metcalf \& Eddy, Inc. (4th Edition ed.) McGraw-Hill Book Company.

Wakawa RJ, Uzairu A, Kagbu JA, Balarabe ML (2008). Impact assessment of effluent discharge on physico-chemical parameters and some heavy metal concentrations in surface water of River Challawa Kano, Nigeria. Afr. J. Pure Appl. Chem. 2(9): 100-106.

Watahiki M, Hata S, Aida $\mathrm{T}$ (1983). $\mathrm{N}_{2} \mathrm{O}$ reduction and inhibition of $\mathrm{N}_{2} \mathrm{O}$ reduction by denitrifying Pseudomonas sp. $220 \mathrm{~A}$ in the presence of oxygen. Agric. Biol. Chem. 47: 1991-1996.

WHO (1985). Guideline for drinking water quality. Drinking-water quality control in small-community Supplies. World Health Organization, Geneva, Switzerland. pp.121. ISBN 9241541709.

WHO (1997a). Guidelines for drinking water quality. $2^{\text {nd }}$ Edition. Recommendations. Geneva: World Health Organization. ISBN 96-4-414503.
WHO (1997b). Guidelines for drinking water quality. $2^{\text {nd }}$ Edition. Surveillance and Control of Community Supplies, Volume 3, World Health Organization, Switzerland, pp. 238. ISBN 924 1545038.

WHO (2011) Guideline for drinking water quality. $4^{\text {th }}$ Edition, Geneva: World Health Organization. ISBN 9789241548151.

Wicander R, Monroe JS (2005) Essentials of Geology, $4^{\text {th }}$ Edition, Brooks Cole, USA, pp. 528. ISBN-10: 049501365X, -13: 9780495013655.

Young WF, Horth H, Crane R, Ogden T, Arnott M (1996). Taste and odour threshold concentrations of potential potable water contaminants. Water Res. 30(2): 331-340.

Yumoto I, Yamazaki K, Hishinuma M, Nodasaka Y, Suemori A, Nakajima K, Inoue N, Kawasaki K(2001). Pseudomonas alcaliphila sp. nov., a novel facultatively psychrophilic alkaliphile isolated from seawater. Int. J. Sys. Evol. Microbiol. 51: 349-355.

Yumoto I, Yamazaki K, Sawabe T, Nakano K, Kawasaki K, Ezura Y, Shinano H (1998). Bacillus horti sp. nov., a new Gram-negative alkaliphilic bacillus. Int. J. Syst. Bacteriol. 48: 1357-1362. 